УДК 316.35

DOI 10.18413/2712-746X-2020-44-3-447-459

\title{
Панельное исследование социального портрета молодого лидера регионального профсоюзного движения
}

\author{
1)Шмарион Ю.В., ${ }^{2)}$ Насонова М.А. \\ 1) Ассоциация социологов «Институт социальных технологий» \\ (Россия, 398050, Липецк, Желябова 12а, офис 2) \\ E-mail: jbshmarion@mail.ru \\ ${ }^{2)}$ Федерация профсоюзов Липецкой области \\ (Россия, 398001, г. Липецк, Советская улица, дом 7, офис 320) \\ E-mail: marina_nasonova@mail.ru
}

\begin{abstract}
Аннотация. Современный молодежный актив региональных профсоюзов приобретает черты нового социального феномена, заслуживающего создание его социального портрета, который станет эмпирической базой, обеспечивающей разработку эффективной системы отбора потенциальных лидеров, их последующего обучения и переподготовки. В связи с отсутствием научных и социально-технологических разработок, посвященных формированию современных молодых лидеров регионального профсоюзного движения, авторами произведена оценка изменения типических характеристик социального портрета молодых лидеров регионального профсоюзного движения, работающих в сложных условиях модели российского трипартизма. Определены особенности изменения характеристик социального портрета молодого лидера при переходе от хронотопа информационной направленности к хронотопу реальных условий повседневной деятельности. Полученные результаты позволяют на научной основе решать вопросы подбора и расстановки профсоюзных кадров, рационально определять структуру и содержание курсовой подготовки профсоюзного актива.
\end{abstract}

Ключевые слова: трипартизм; социальный портрет молодого профсоюзного лидера; формирование кадрового резерва профсоюзов, панельное исследование.

Для цитирования: Шмарион Ю.В., Насонова М.А. 2020. Панельное исследование социального портрета молодого лидера регионального профсоюзного движения. NOMOTHETIKА: Философия. Социология. Право. 45 (3): 447-459. DOI 10.18413/2712-746X-2020-44-3-447-459

\section{Panel study of the social portrait of the young leader of the regional trade union movement}

\author{
${ }^{1)}$ Yuri V. Shmarion, ${ }^{2)}$ Marina A. Nasonova \\ ${ }^{1)}$ Association of sociologists "Institute of social technologies" \\ 12A Zhelyabova, office 2, Lipetsk, 398050, Russia \\ E-mail: jbshmarion@mail.ru \\ ${ }^{2)}$ Federation of trade unions of Lipetsk region \\ 7 Sovetskaya street, office 320, Lipetsk, 398001, Russia \\ E-mail: marina_nasonova@mail.ru
}

\begin{abstract}
The modern youth activism of regional trade unions acquires the features of a new social phenomenon that deserves to create a social portrait of it, which will become an empirical basis for developing an effective system for selecting potential leaders, their subsequent training and retraining. Due to the lack of scientific and socio-technological developments devoted to the formation of modern young leaders of the regional trade Union movement, the authors evaluated the changes in the typical
\end{abstract}


characteristics of the social portrait of young leaders of the regional trade Union movement working in the difficult conditions of the Russian tripartism model. The features of changing the characteristics of the social portrait of a young leader during the transition from the chronotope of information orientation to the chronotope of real conditions of daily activity are determined. The results obtained allow us to solve the issues of selection and placement of trade Union personnel on a scientific basis, and rationally determine the structure and content of the course training of trade Union assets.

Key words: tripartism; social portrait of a young trade Union leader; formation of the personnel reserve of trade unions, panel study.

For citation: Shmarion Yu.V., Nasonova M.A. 2020. Panel study of the social portrait of the young leader of the regional trade union movement. NOMOTHETIKA: Philosophy. Sociology. Law series. 45 (3): 447-459 (in Russian). DOI 10.18413/2712-746X-2020-44-3-447-459

\section{Введение}

В современном обществе профсоюзы представляют собой один из высоко организованных институтов гражданского общества, который оказывает реальную помощь работникам в отстаивании их законных прав и свобод. Отдельному работнику трудно отстоять свои права в условиях трипартизма, ведь и государство, и работодатели располагают более мощной правовой поддержкой. Эта проблемная ситуация сегодня особенно актуальна практически во всех странах, так как снижается активность рабочего движения и отмечается продвижение идей неолиберализма. По данным U.S. bureau of labor statistics [Union membership..., 2018], начиная с 1940-х и 1950-х годов в профсоюзах состояли $30 \%$ американских рабочих, в 1980 году - около 20 \%, в 2017 и 2016 годах членство в профсоюзах продолжало сокращаться и достигло 10,7 \%, а в 2018 году упало до 10,5 \%. Тенденция снижения членства в профсоюзах отмечается и в других странах мира. По данным Organisation for Economic Cooperation and Development (OECD) [Visser, 2017] в 2017 году численный состав профсоюзов составлял в Швеции - 66,7 \%, в Италии - 35,4 \%, в Англии $-23,5 \%$, в Японии - 17,1 \%, в Германии - 16,6 \%, В Южной Корее -10,4 \%.

В таких сложных условиях возрастает роль лидера профсоюзной организации как основной управленческой единицы профсоюза. «Сильные профсоюзы возникают тогда, когда их члены информированы, образованны и активны, - пишут руководители AFSCME Ли Сондерс и Элисса Макбрайд. - Поэтому наиболее эффективными местными профсоюзными лидерами являются те, кто постоянно ищет новые пути вовлечения рядовых сотрудников в качестве действительно активных участников ведения профсоюзного дела». [Green, 2018]. В этой связи одной из современных актуальных проблем региональных профсоюзов является проблема формирования профсоюзного актива и поиска активного члена профсоюза, который может стать во главе профсоюзной организации.

В региональных профсоюзах молодые специалисты все чаще занимают ключевые позиции. Очевидно, что профсоюзный лидер должен быть политически грамотен, иметь хорошую правовую подготовку, обладать высоким уровнем политической, управленческой и социально-технологической культуры [Каким должен...2018]. Таким образом, современный молодежный актив региональных профсоюзов приобретает черты нового социального феномена, заслуживающего создание его социального портрета, который станет основанием теоретического осмысления этого феномена и будет эмпирической базой, обеспечивающей разработку эффективной системы отбора потенциальных лидеров, последующего обучения и переподготовки. В рассмотренных выше зарубежных источниках, а также в отечественных публикациях о профсоюзах отсутствуют исследования подобного направления, что к приводит к преобладанию интуитивного отбора кандидатур на лидерские позиции, и соответственно доминированию традиционного и неэффективного подхода к обучению и переподготовки лидеров профсоюза. Отсутствие научных и социально-технологических разработок, посвященных формированию современных молодых лидеров регионального проф- 
союзного движения определило цель данной работы, направленной на выявление актуальных характеристик социального портрета молодого лидера и использования их для разработки социальных технологий подготовки молодых лидеров профсоюзов.

Гипотеза исследования: характеристики социального портрета молодого лидера регионального профсоюзного движения зависят от хронотопа, в котором реализуются социальные взаимодействия молодого лидера, при этом разница в показателях характеристик социального портрета определяет структуру и содержание курсов повышения квалификации молодых лидеров профсоюза.

Панельные социологические исследования проводились среди участников Молодежного профсоюзного форума Липецкой области 25.01.2019, и эти же участники были опрошены 25.02.2019 на своих рабочих местах по той же самой анкете. Выборочная совокупность формировалась по методу основного массива.

\section{Научные результаты и дискуссия}

Среди молодых лидеров отмечается гендерный дисбаланс - активистов девушек в два раза больше $(67,4$ \%), чем юношей $(32,6$ \%). Несмотря на реальные трудности [Шмарион, 2018] современной профсоюзной деятельности девушки оказываются более активны, чем юноши. Отметим, что гендерный дисбаланс профсоюзной активности отмечается также на Западе [Пато, 2006]. По данным ВЦИОМ, российские женщины-лидеры профсоюза активно осваивают позитивный опыт мужчин, в результате термин «феминизм» оказался чуждым массовому сознанию активистов профсоюза [Карабайкина, 2018].

В возрастной структуре молодежного актива представлена не только молодежь, но и старшая возрастная группа (более 30 лет), которая равномерно распределена среди актива.

Образовательный уровень молодых лидеров достаточно высок. Большинство (79,1\%) имеет высшее образование. Среди молодежного актива выделены 4 стажевые группы: начинающие (20,9 \%, стаж до года), опытные активисты $(39,5 \%$, стаж от 1 до 3 лет), кадровый резерв (18,6 \%, стаж от 4 до 7 лет), ветераны молодежного актива (21,0\%, стаж от 8-15 лет), которые по-прежнему активно участвуют в решении молодежных проблем.

Социально-демографические характеристики молодежного профсоюзного актива только предваряют социальный портрет. Основной системно-интегральной характеристикой профсоюзного лидера является активность. Согласно Петровскому А.В. [1976], активность как деятельное состояние субъекта детерминирована изнутри, со стороны его отношений к миру, и реализуется во вне - в процессах поведения. Активность профсоюзного лидера обусловлена следующей триадой основы активности: мотивационной, целевой, инструментальной. Анализ побудительных мотивов позволяет уточнить, как изменяется структура мотивационного ядра молодых активистов, проявляющаяся в разных хронотопах (рис. 1, здесь и на последующих рисунках: красный цвет - опрос во время участия в работе Форума 25.01.2019 (Ф), синий - опрос на рабочих местах 25.02.2019 (Р)).

В ранжированном ряду факторов в хронотопе информационно-просветительской направленности (хронотоп ИПН) (см. рис.1) в четверку первых вошли стремление самореализоваться $(60,5 \%)$, интерес $(53,5 \%)$ и стремление быть полезным обществу $(48,8 \%)$, приобретение опыта управленческой деятельности (39,5\%). В хронотопе повседневности в четверке несколько иной состав: стремление самореализоваться $(39,0 \%)$, стремление самоутвердиться (31,7 \%), интерес и стремление быть полезным обществу (по 24,4 \%), приобретение опыта управленческой деятельности (19,5 \%).

В структуре факторного пространства лидирующая четверка факторов определяет те мотивы, от которых в основном зависит выбор молодого работника, желающего стать лидером профсоюзного движения, потребность к обучению, учению, самоорганизации, самоуправлению. 


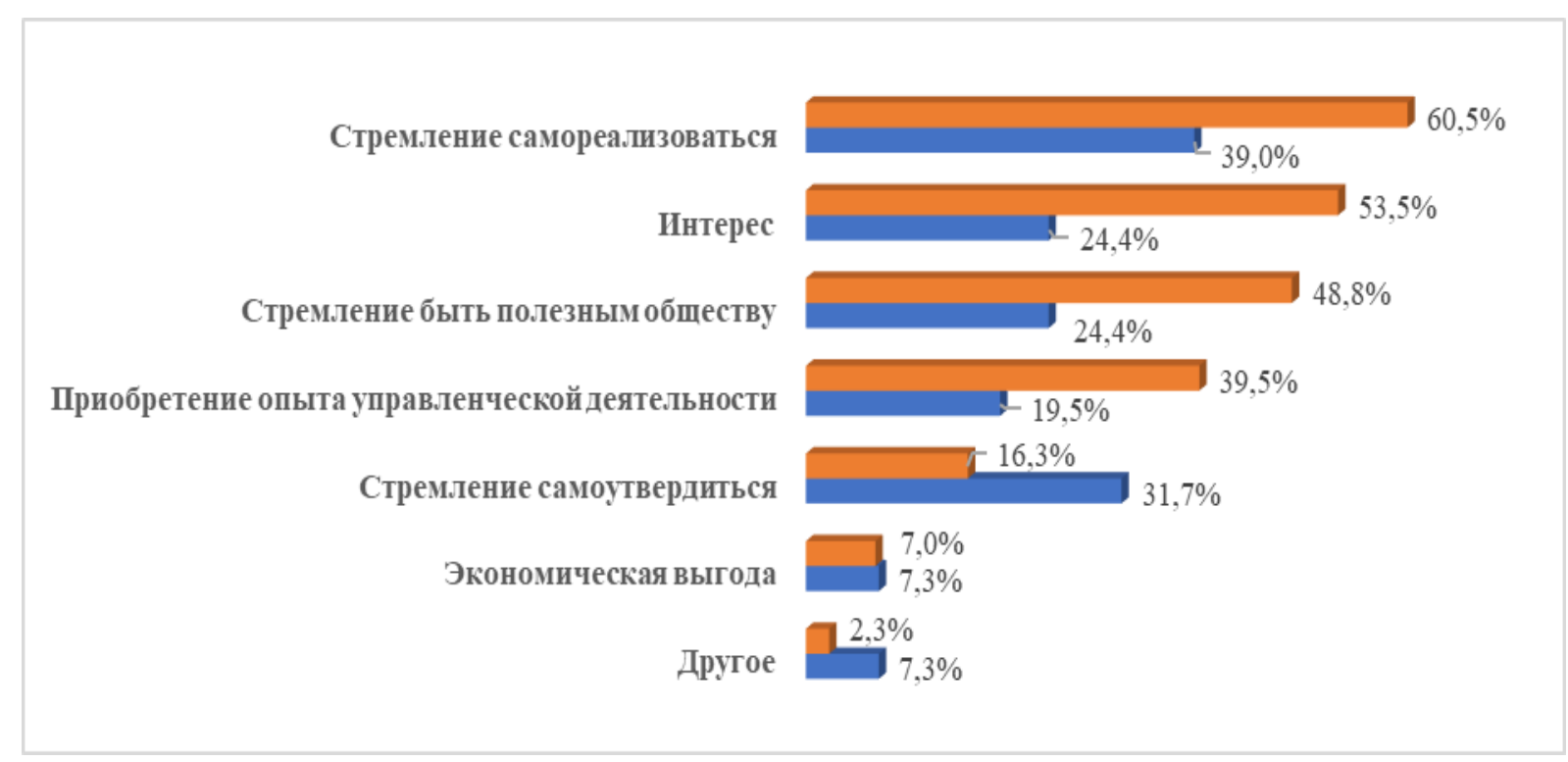

Рис. 1. Изменение интенсивности факторов, побуждающих профсоюзного лидера к его активной деятельности в зависимости от места и времени опроса

Fig. 1. Changes in the intensity of factors that encourage the trade Union leader to be active, depending on the place and time of the survey

При переходе от одного хронотопа к другому интенсивность проявления основных факторов уменьшилась в 1,5-2 раза (табл. 1), а структура факторного пространства практически осталась неизменной, за исключением одного фактора - стремления самоутвердиться (см. рис. 1).

Таблица 1 Table 1

Направление и интенсивность тренда факторного пространства, побуждающего профсоюзного лидера к его активной деятельности

The direction and intensity of the factor space trend that encourages the trade Union leader to be active

\begin{tabular}{|c|c|c|c|c|}
\hline \multirow{2}{*}{$\begin{array}{c}\text { Факторы, } \\
\text { побуждающие лидера } \\
\text { к активной деятельности }\end{array}$} & \multicolumn{2}{|c|}{ Дата опроса } & \multirow{2}{*}{$\begin{array}{l}\text { Отклонение } \\
\text { (Р-Ф) }\end{array}$} & \multirow{2}{*}{$\begin{array}{c}\text { Направление } \\
\text { тренда } \\
\text { и его } \\
\text { интенсивность } \\
\end{array}$} \\
\hline & $\begin{array}{c}\text { 25.02.2019 } \\
\text { Рабочее место (Р) }\end{array}$ & $\begin{array}{l}25.01 .2019 \\
\text { Форум }(\Phi) \\
\end{array}$ & & \\
\hline Интерес & $24,39 \%$ & $53,49 \%$ & $-29,10 \%$ & $-2,19$ \\
\hline $\begin{array}{l}\text { Приобретение опыта } \\
\text { управленческой } \\
\text { деятельности }\end{array}$ & $19,51 \%$ & $39,53 \%$ & $-20,02 \%$ & $-2,03$ \\
\hline $\begin{array}{l}\text { Стремление быть полезным } \\
\text { обществу }\end{array}$ & $24,39 \%$ & $48,84 \%$ & $-24,45 \%$ & $-2,00$ \\
\hline $\begin{array}{l}\text { Стремление } \\
\text { самореализоваться }\end{array}$ & $39,02 \%$ & $60,47 \%$ & $-21,44 \%$ & $-1,55$ \\
\hline $\begin{array}{l}\text { Экономическая } \\
\text { выгода }\end{array}$ & $7,32 \%$ & $6,98 \%$ & $0,34 \%$ & 1,05 \\
\hline $\begin{array}{l}\text { Стремление } \\
\text { самоутвердиться }\end{array}$ & $31,71 \%$ & $16,28 \%$ & $15,43 \%$ & 1,95 \\
\hline Другое & $7,32 \%$ & $2,33 \%$ & $4,99 \%$ & 3,15 \\
\hline
\end{tabular}


В хронотопе повседневности (хронотоп ПВ) этот фактор приобретает для молодых лидеров особую значимость, так как социальное пространство имеет более сложную структуру, определяемую условиями реального многообразия жизнедеятельности молодого лидера профсоюзов [Социальные технологии..., 1995].

Неизменность структуры факторного пространства подтверждается достаточно высоким уровнем рангового коэффициента корреляции Спирмена $-\mathrm{r}=-0,68$, который является значимым. Так как $\mathrm{t}_{\text {эмпир }}=2,02>\mathrm{t}_{\text {крит }}=0,79$ для $\mathrm{n}=7$ и $\mathrm{P}(\mathrm{x})=95 \%$.

Установлено, что 60 \% значения r определяется двумя факторами: интерес, влияние которого в хронотопе ПВ снижается в 2,19 раза, и стремление самоопределиться, значимость которого возрастает в 1,95 раза (см. табл. 1 ).

Этот факт требует более глубокого социально-психологического анализа. Абрахам Маслоу относил стремление самоутвердиться к высшим человеческим потребностям [Маслоу, 2014]. Психологи утверждают [Профессиональная..., 2009], что контроль самоутверждения человека может определяться в зависимости от доминирования внешнего или внутреннего локус контроля, причем второй является предпочтительным. Социальное пространство реальной жизнедеятельности молодого лидера многомерно. Ключевым мотивом самоутверждения лидера будет желание обрести достойное место в социуме.

Количественно-качественный анализ показал, что в реальных условиях существенно возрастает (почти в 2 раза) влияние фактора самоутверждения на активность профсоюзной деятельности, обусловленное сложностью и многомерностью хронотопа ПВ. Следовательно, при организации повышения квалификации молодых лидеров надо предусмотреть формирование тех характеристик социального портрета, которые определяются хронотопом ПВ. Целевые установки саморазвития, самореализации лидера должны быть достаточно высокими и ориентированными на процесс совершенствования личности и определяться хронотопом ИПН.

Структура мотивационного ядра каждого человека находит отражение в его деятельности, которая раскрывает весь спектр как позитивных, так и негативных качеств. Среди представленных для обсуждения качеств профсоюзного лидера в первую пятерку в хронотопе ИПН вошли: уверенность в себе - 58,1 \%, способность представлять и отстаивать интересы коллектива - 53,5 \%, активная жизненная позиция - 53,5 \%, умение создать команду - 53,5 \%, коммуникабельность - 48,8 \%.

В хронотопе ПВ первая пятерка претерпела изменения: умение создать команду 46,3 \%, надёжность, ответственность и последовательность - 46,3\%, гибкость поведения и чувствительность к ситуации - 41,5 \%, уверенность в себе - 39,0 \%, активная жизненная позиция - 39,0 \%. При этом в разных хронотопах в первую пятерку актуальных качеств попали уверенность в себе - 58,1 \% (1 место Ф) и 39,0 \% (4 место Р), активная жизненная позиция - 53,5 \% (3 место Ф) и 39,0 \% (5 место Р), умение создать команду - 48,8 \% (5 место Ф) и $46,3 \%$ (1 место Р) (рис. 2).

В хронотопе ПВ у молодого лидера оказываются более актуальными другие личностные качества: надежность, ответственность, последовательность (46,3 \% (2 место Р)), гибкость поведения и чувствительность к ситуации (41,5 \% (4 местоР)), что свидетельствует о многофакторности и многомерности социального пространства этого хронотопа. 


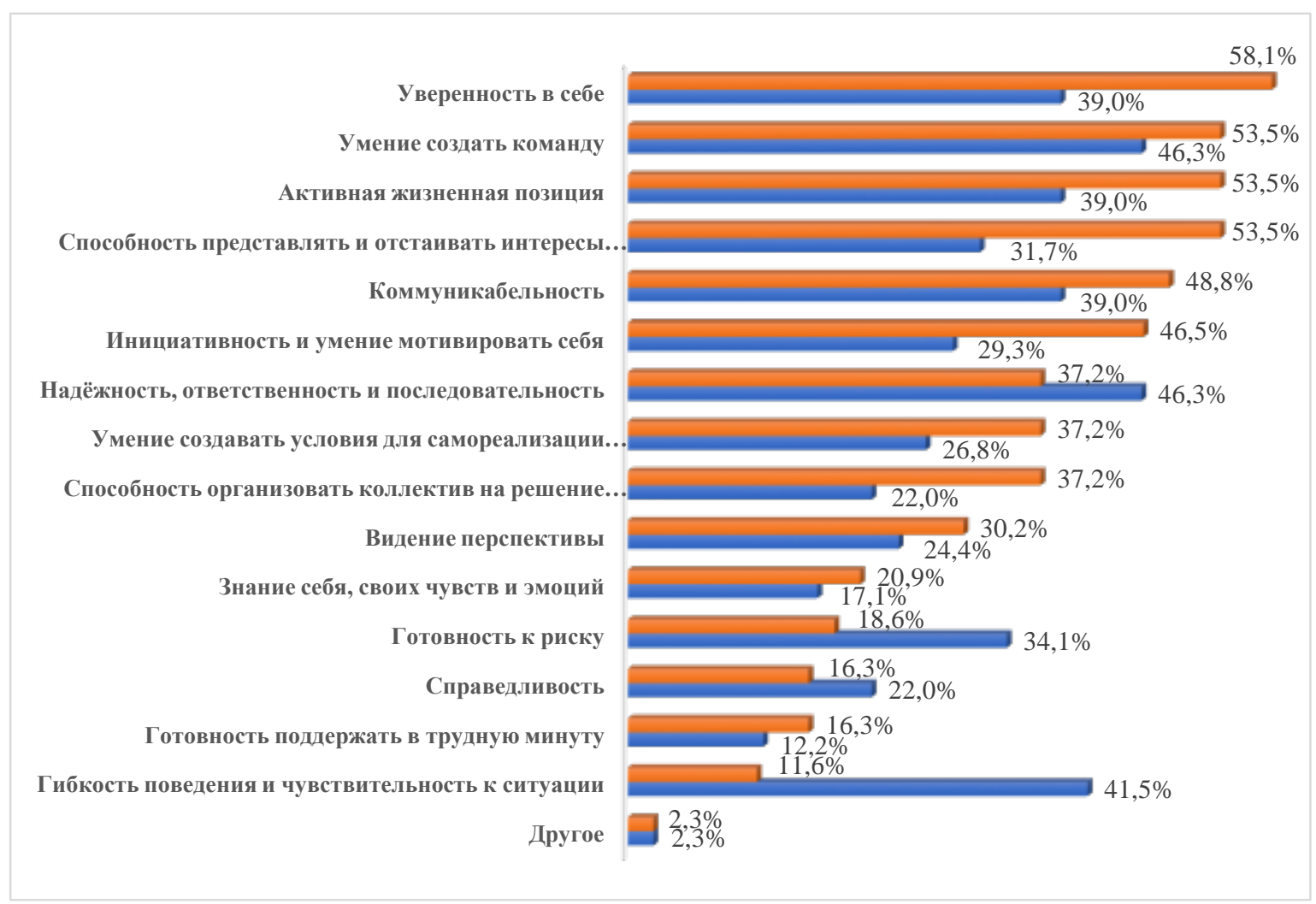

Рис. 2. Изменение уровня актуализации личностных качеств профсоюзного лидера, побуждающих его к активной деятельности в зависимости от места и времени опроса Fig. 2. Changes in the level of actualization, personal qualities of the trade Union leader that encourage him to be active, depending on the place and time of the survey

В реальных условиях трудовой деятельности молодого лидера актуализация около 70 \% перечисленных личностных качеств, необходимых для эффективной профсоюзной деятельности, существенно снизилась (в 1,15-1,7 раза), а актуальность таких качеств, как надёжность, ответственность и последовательность, справедливость, готовность к риску, гибкость поведения и чувствительность к ситуации возросла (в 1,25- 3,57 раза) (табл. 2).

Уменьшение и возрастание актуализации личностных качеств при переходе из хронотопа ИПН в хронотоп ПВ не привело к значимому изменению структуры актуальных личностных характеристик, о чем свидетельствует умеренный уровень значимого рангового коэффициента корреляции Спирмена $r=0,49,\left(\mathrm{t}_{\text {эмпир }}=1,86>\mathrm{t}_{\text {крит }}=0,441\right.$ для $\mathrm{n}=16$ и $\mathrm{P}(\mathrm{x})=95 \%)$. Установлено, что изменение структуры личностных качеств в хронотопе ПВ определяется на 50 \% возросшей актуальностью качества гибкость поведения и чувствительность к ситуации; на $62 \%$ - гибкость поведения и чувствительность к ситуации, плюс надёжность, ответственность и последовательность; на 78,5 \% - гибкость поведения и чувствительность к ситуации, плюс надёжность, ответственность и последовательность, плюс готовность к риску, плюс способность представлять и отстаивать интересы коллектива.

Отмечается снижение в 1,5 раза у молодых лидеров уверенности в себе в хронотопе ПВ, по сравнению с хронотопом ИПН, в рамках которого 58,1 \% молодых лидеров считали это личностное качество актуальным.

Уверенный в себе профсоюзный лидер - явление позитивное для трудового коллектива. Он оказывает положительное влияние на состояние морально-психологического климата в коллективе, престиж профсоюзной организации и организации в целом. 
Направление и интенсивность тренда показателей личностных качеств профсоюзного лидера, необходимых для его активной деятельности The direction and intensity of the trend of indicators of personal qualities of a trade Union leader necessary for his active activity

\begin{tabular}{|c|c|c|c|c|}
\hline \multirow[b]{2}{*}{$\begin{array}{c}\text { Актуальные качества } \\
\text { молодого лидера }\end{array}$} & \multicolumn{2}{|c|}{ Дата опроса } & \multirow[b]{2}{*}{$\begin{array}{l}\text { Отклонение } \\
\text { (Р-Ф) }\end{array}$} & \multirow{2}{*}{$\begin{array}{c}\text { Направление } \\
\text { тренда } \\
\text { и его } \\
\text { интенсивность }\end{array}$} \\
\hline & $\begin{array}{l}25.02 .2019 \\
\text { Работа (Р) }\end{array}$ & $\begin{array}{l}25.01 .2019 \\
\text { Форум (Ф) }\end{array}$ & & \\
\hline $\begin{array}{l}\text { Способность организовать } \\
\text { коллектив } \\
\text { на решение поставленных задач }\end{array}$ & $21,95 \%$ & $37,21 \%$ & $-15,26 \%$ & $-1,70$ \\
\hline $\begin{array}{l}\text { Способность представлять } \\
\text { и отстаивать } \\
\text { интересы коллектива }\end{array}$ & $31,71 \%$ & $53,49 \%$ & $-21,78 \%$ & $-1,69$ \\
\hline $\begin{array}{l}\text { Инициативность и умение мотивировать } \\
\text { себя }\end{array}$ & $29,27 \%$ & $46,51 \%$ & $-17,24 \%$ & $-1,59$ \\
\hline Уверенность в себе & $39,02 \%$ & $58,14 \%$ & $-19,12 \%$ & $-1,49$ \\
\hline $\begin{array}{l}\text { Умение создавать условия для самореа- } \\
\text { лизации своих последователей }\end{array}$ & $26,83 \%$ & $37,21 \%$ & $-10,38 \%$ & $-1,39$ \\
\hline Активная жизненная позиция & $39,02 \%$ & $53,49 \%$ & $-14,46 \%$ & $-1,37$ \\
\hline $\begin{array}{l}\text { Готовность поддержать в трудную ми- } \\
\text { нуту }\end{array}$ & $12,20 \%$ & $16,28 \%$ & $-4,08 \%$ & $-1,33$ \\
\hline Коммуникабельность & $39,02 \%$ & $48,84 \%$ & $-9,81 \%$ & $-1,25$ \\
\hline Видение перспективы & $24,39 \%$ & $30,23 \%$ & $-5,84 \%$ & $-1,24$ \\
\hline Знание себя, своих чувств и эмоций & $17,07 \%$ & $20,93 \%$ & $-3,86 \%$ & $-1,23$ \\
\hline Умение создать команду & $46,34 \%$ & $53,49 \%$ & $-7,15 \%$ & $-1,15$ \\
\hline Другое & $2,33 \%$ & $2,33 \%$ & $-2,33 \%$ & 1,00 \\
\hline $\begin{array}{l}\text { Надёжность, ответственность } \\
\text { и последовательность }\end{array}$ & $46,34 \%$ & $37,21 \%$ & $9,13 \%$ & 1,25 \\
\hline Справедливость & $21,95 \%$ & $16,28 \%$ & $5,67 \%$ & 1,35 \\
\hline Готовность к риску & $34,15 \%$ & $18,60 \%$ & $15,54 \%$ & 1,84 \\
\hline $\begin{array}{l}\text { Гибкость поведения } \\
\text { и чувствительность к ситуации }\end{array}$ & $41,46 \%$ & $11,63 \%$ & $29,84 \%$ & 3,57 \\
\hline
\end{tabular}

Для молодого лидера в хронотопе ПВ оказываются важными такие качества, как умение создать команду, активная жизненная позиция, так как профсоюзная работа - это командная работа. Активная жизненная позиция предполагает социально-активное отношение лидера к окружающей социально-экономической действительности, а также активное ее преобразование [Бородихина, 2015; Задевалова, 2012].

Таким образом, анализ актуальных личностных качеств позволил оценить набор актуальных качеств лидера и необходимые коррективы в системе повышения квалификации.

О необходимости совершенствования системы подготовки профсоюзного актива свидетельствуют результаты балльной самооценки собственных лидерских качеств молодыми лидерами (рис. 3). 


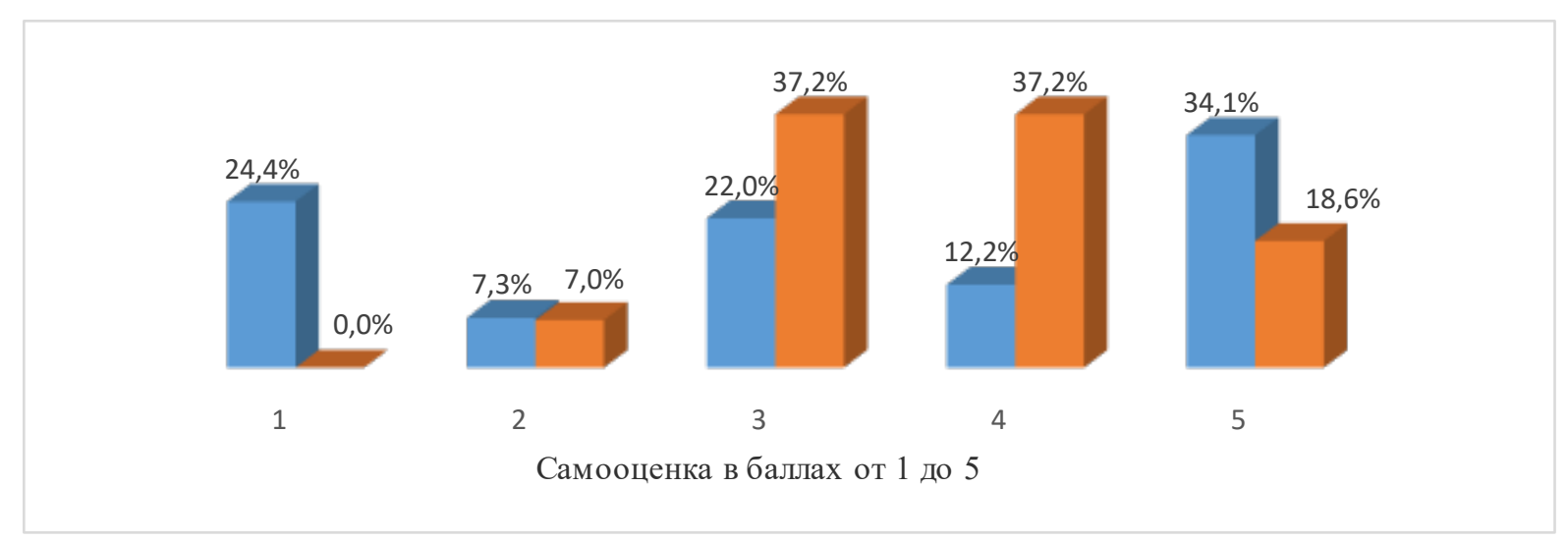

Рис. 3. Уровень балльной самооценки лидерских качеств молодых лидеров в зависимости от места и времени опроса

Fig. 3. The level of self-assessment of leadership qualities of young leaders depending on the place and time of the survey

Структура самооценки лидерских качеств претерпела существенные изменения при переходе от одного хронотопа к другому. В хронотопе ПВ повседневности 4 из 10 лидеров, встретившись с конкретными трудно разрешимыми проблемами, приходят к выводу, что уровень их лидерских качеств недостаточен (самооценка равна единице), и, скорее всего, они переведут сложные проблемы в разряд неразрешимых (см. рис. 3). Вероятно, что такой же стратегии будут придерживаться 7,3 \% лидеров, которые оценили на двойку свои лидерские качества.

Треть молодых лидеров, у которых сформирована команда, текущая профсоюзная работа в конкретной организации спорится, оценили свои лидерские качества на отлично, хотя на Форуме их оценки были в два раза скромнее. Установлено, что оценки удовлетворительно и хорошо 74,4 \% молодых лидеров в режиме «Форум» не нашли подтверждения в реальной среде. Особенно это проявилось у лидеров, которые считали, что они обладают хорошими лидерскими качествами. В реальной жизни это подтвердилось лишь у каждого третьего их них.

Изменение оценки лидером собственных качеств в разных хронотопах при переходе из хронотопа ИПН в хронотоп ПВ при прочих равных условиях будет определяться изменением интенсивности воздействия на лидера факторов, препятствующих его управленческой деятельности в конкретной профсоюзной организации, а также тем, как воздействует на молодого лидера изменение интенсивности конкретного фактора (табл. 3).

В хронотопе ИПН лидер получает актуальную информацию о новых формах и методах управления и оценивает объём времени внедрения новшеств. Более половины (51,2 \%) посчитали, что им не хватит времени на внедрение новшеств. В хронотопе ПВ лидеру становится очевидным, что новые методы он не сможет внедрить из-за ограниченности ресурсов, поэтому выбирается наименее трудоемкая и малоэффективная часть новшества, которую можно внедрить за минимальное время. В результате проблема нехватки времени разрешается, но новшество внедряется частично, без должного эффекта. В хронотопе ПВ у лидеров возрастает потребность в актуальной информации об управленческой деятельности.

Если в хронотопе ИПН было два из десяти лидеров, желающих получить такую информацию, то в ПВ их стало в два раза больше. Следовательно, этот факт необходимо учесть в корректировке курсов повышения квалификации лидеров. 
Направление и интенсивность тренда факторов,

препятствующих управленческой деятельности лидера в зависимости от хронотопа

The direction and intensity of the trend

of factors that hinder the leader's managerial activity, depending on the chronotope

\begin{tabular}{|c|c|c|c|c|}
\hline \multirow{2}{*}{$\begin{array}{c}\text { Факторы, } \\
\text { препятствующие } \\
\text { молодому лидеру }\end{array}$} & \multicolumn{2}{|c|}{ Дата и место опроса } & \multirow{2}{*}{$\begin{array}{l}\text { Отклонение } \\
(\mathrm{P}-\Phi)\end{array}$} & \multirow{2}{*}{$\begin{array}{c}\text { Направление } \\
\text { тренда } \\
\text { и его } \\
\text { интенсивность } \\
\end{array}$} \\
\hline & $\begin{array}{l}25.02 .2019 \\
\text { Работа (P) }\end{array}$ & $\begin{array}{l}25.01 .2019 \\
\text { Форум (Ф) }\end{array}$ & & \\
\hline Отсутствие времени & $34,1 \%$ & $51,2 \%$ & $-17,0 \%$ & $-1,50$ \\
\hline $\begin{array}{l}\text { Непонимание окружающими моего } \\
\text { желания принимать участие } \\
\text { в управленческой деятельности } \\
\text { профсоюзной организации }\end{array}$ & $17,1 \%$ & $30,2 \%$ & $-13,2 \%$ & $-1,77$ \\
\hline Другое & $7,3 \%$ & $14,0 \%$ & $-6,6 \%$ & $-1,91$ \\
\hline Неудачный опыт & $2,3 \%$ & $2,3 \%$ & $0 \%$ & 1,00 \\
\hline $\begin{array}{l}\text { Отсутствие информации } \\
\text { о возможности такой } \\
\text { деятельности }\end{array}$ & $39,0 \%$ & $20,9 \%$ & $18,1 \%$ & 1,86 \\
\hline $\begin{array}{l}\text { Недоверие к профсоюзным } \\
\text { организациям }\end{array}$ & $4,9 \%$ & $2,3 \%$ & $2,6 \%$ & 2,10 \\
\hline
\end{tabular}

Анализ результатов панельного исследования показал, что в разных хронотопах профсоюзные лидеры отдают предпочтение разным методам воздействия на политическую власть, по существу реализуя ситуативный подход к управлению [Поспелов, 1986]. В хронотопе ИПН 72,1 \% молодых лидеров считают, что с властью можно договориться в рамках личных встреч с руководителями. Вторым методом (55,8 \%) для разрешения проблем, возникших в системе трипартизма, в СМИ как к четвертой власти [Сафарян, 2008].

В хронотопе ПВ молодые лидеры более конкретно и критично оценивают возможность организовать личную встречу с высокопоставленным чиновником, и в связи с этим такая возможность сохранилась только у 41,5 \% лидеров, т.е. снизилась в 1,7 раза.

В хронотопе ПВ лидеры стали больше надеяться на СМИ (46,3 \%), чем на личные встречи, ориентируясь воздействовать на власть через оппозицию $(34,1 \%)$, в то время как в хронотопе ИПН (2,3 \%) такая возможность не представлялась реальной для большинства лидеров. В хронотопе ПВ для лидеров теряют актуальность митинги и демонстрации (в 2,4 раза), пикеты правительственных зданий (в 1,4 раза), и одновременно с этим возрастает актуальность обращения в суды (в 1,2 раза), голодовок и забастовок (в 6,4 раза).

Таким образом, в системе трипартизма молодому лидеру необходимо проявлять особую гибкость в отстаивании ключевых интересов профсоюза. Кроме того, необходимо учитывать мнение молодых лидеров о том, что региональные профсоюзы не обладают полной независимостью в принимаемых решениях, так как только одно из трех решений профсоюз принимает самостоятельно. Следовательно, в курсовой подготовке необходимо обратить внимание на формирование у молодых лидеров знаний, умений и навыков политического анализа состояния регионального сообщества.

Анализ когнитивных потребностей молодых лидеров показал, что в хронотопе ПВ сместились акценты актуальности в сторону тех дисциплин, которые обеспечивают решение оперативных реальных задач управления (табл. 4.) 
Самооценка направления и интенсивности

актуализации когнитивных потребностей лидеров в зависимости от хронотопа

Self-assessment of the direction and intensity

of actualization of their cognitive needs of leaders, depending on the chronot

\begin{tabular}{|c|c|c|c|c|}
\hline \multirow[b]{2}{*}{ Дисциплины } & \multicolumn{2}{|c|}{ Дата и место опроса } & \multirow{2}{*}{$\begin{array}{c}\text { Отклоне- } \\
\text { ние } \\
(\mathrm{P}-\Phi)\end{array}$} & \multirow{2}{*}{$\begin{array}{c}\text { Направление } \\
\text { тренда и его } \\
\text { интенсивность }\end{array}$} \\
\hline & $\begin{array}{l}25.02 .2019 \\
\text { Работа (Р) }\end{array}$ & $\begin{array}{l}25.01 .2019 \\
\text { Форум (Ф) }\end{array}$ & & \\
\hline Иностранные языки & $4,9 \%$ & $53,5 \%$ & $-48,6 \%$ & $-10,97$ \\
\hline Социальные технологии & $12,2 \%$ & $27,9 \%$ & $-15,7 \%$ & $-2,29$ \\
\hline Связи с общественностью (PR) & $31,7 \%$ & $55,8 \%$ & $-24,1 \%$ & $-1,76$ \\
\hline Менеджмент & $14,6 \%$ & $14,0 \%$ & $0,6 \%$ & 1,05 \\
\hline Информационные технологии & $43,9 \%$ & $25,6 \%$ & $18,3 \%$ & 1,72 \\
\hline Социальное проектирование & $56,1 \%$ & $27,9 \%$ & $28,2 \%$ & 2,01 \\
\hline
\end{tabular}

Когнитивные потребности лидеров системно интегрированы в три блока знаний: коммуникативный, социально-технологический и управленческий (в порядке снижения потребности). В коммуникативном блоке - знания о связи с общественностью. В социально-технологическом блоке - знания о социальных и информационных технологиях, социальном проектировании. В управленческом - знания о социальном управлении и менеджменте. Для молодых лидеров является характерным фронтальная актуальная когнитивная потребность, которая при изменении хронотопа изменяет свою структуру. В хронотопе ИПН 52,5 \% лидеров хотели осваивать иностранные языки, а в хронотопе ПВ желающих уменьшилось в 10,97 раза (см. табл. 4). А потребность в освоении информационных технологий в хронотопе повседневности возросла в 1,72 раза и в 2,01 раза увеличилась потребность в освоении процедур социального проектирования. Снизилась потребность в знаниях по связям с общественностью в 1,76 раза, социальных технологий - в 2,29 раза. Этот факт требует отдельного рассмотрения, так как в универсальном управленческом алгоритме, предложенном академиком Афанасьевым В.Г. в работе «Научное управление обществом» [1968] и развитом Ж.Т. Тощенко [2011], социальное проектирование и социальные технологии - две логично связанные между собой укрупненные процедуры, причем социальные технологии оказываются востребованными на финишных этапах универсального управленческого алгоритма.

Отмечается снижение в хронотопе ПВ потребности знаниях PR-деятельности и связанное с этим снижение уровня взаимодействия со СМИ, что затруднит создание позитивного имиджа профсоюзной организации в региональном сообществе.

Изменение хронотопов не повлияло на уровень востребованности лидерами информационных технологий, используемых в деятельности профсоюзной организации. Использование цифровых технологий широко обсуждается в американских профсоюзах. Джеймс Уолш, защитник труда отмечает: «...цифровые инструменты могут помочь в этом создании и поддержке низового руководства. Снизу-вверх переход на цифровые технологии с профсоюзной организацией является эффективным средством модернизации усилий Союза и привлечения членов» [Green, 2018]. 
Сохранилось неизменной отношение молодых лидеров к современной России, что вполне естественно. Получены близкие по структуре данные, характеризующие желание молодых лидеров активно участвовать в общественной жизни. Отмеченные рассогласования определяются конкретной социальной средой и реальными ресурсами для разрешения проблем. Установлено, что активность лидеров в решении общественных проблем поддерживается в основном молодежными движениями и профсоюзами, в то время как органы власти и СМИ недостаточно внимания уделяют позитивным начинаниям молодых лидеров регионального профсоюзного движения.

\section{Заключение}

Анализ и обобщение результатов панельного исследования позволили сделать следующие выводы:

1. Установлено, что профессиональные и личностные качества молодого лидера регионального профсоюзного движения имеют триадную структуру, включающую базовую (инвариантную) часть, определяемую социетальными параметрами социальной среды; особенную часть, определяемую региональными параметрами социальной среды; специфическую часть, определяемую спецификой отраслевой принадлежности профсоюзной организации.

2. При переходе от хронотопа к хронотопу отмечается изменение характеристик социального портрета лидера. Основное влияние на изменение структуры характеристик социального портрета в последующем хронотопе оказывают компоненты характеристики, стоящие на первых и последних местах ранжированного ряда компонент данной характеристики, полученных на предыдущем хронотопе.

3. Изменение структуры характеристики социального портрета может быть оценено с помощью непараметрического рангового коэффициента корреляции Спирмена. Результаты промежуточных расчетов коэффициента корреляции Спирмена позволяют оценить долевое участие отдельных компонент характеристики социального портрета в изменении структуры.

4. Доказано, что разницу в показателях характеристик социального портрета, полученную при переходе от хронотопа ИПН к хронотопу ПВ, целесообразно использовать при определении структуры и содержания курсов повышения квалификации молодых лидеров.

5. Желание молодых лидеров повысить свою квалификацию инвариантно изменениям хронотопов.

Таким образом, результатом проведения данного панельного социологического исследования стало определение особенностей изменения характеристик социального портрета молодого лидера регионального профсоюзного движения, при переходе от хронотопа ИПН к хронотопу ПВ, что позволило решать вопросы подбора и расстановки профсоюзных кадров, определить рациональную структуру и содержание курсовой подготовки как профсоюзного актива, так и молодых лидеров регионального профсоюзного движения. Для данного класса задач разработаны методологические и методические подходы представления, обработки и интерпретации эмпирических данных.

Результаты данной работы были доложены в августе 2019 г. на заседании Совета ассоциации территориальных объединений организаций профсоюзов Центрального федерального округа, посвященном молодежной политики профсоюзов, и получили одобрение.

\section{Список источников}

1. Каким должен быть профсоюзный лидер? 2018. Профсоюзная библиотека Федерации профсоюзов Красноярского края. URL: http://www.fpkk.ru/read.php?articlealias=sb1 150723865 (дата обращения: 12 октября 2019).

2. Петровский А.В. 1976. Общая психология. Москва, Просвещение, 476 с. 
3. Социальные технологии: Толковый словарь. 1995. Отв. ред. В.Н. Иванов. МоскваБелгород: Луч-Центр социальных технологий, 309 с.

4. Тощенко Ж.Т. 2011. Социология управления. М.: Центр социального прогнозирования и маркетинга, $300 \mathrm{c}$.

5. Профессиональная самореализация личности в современном обществе: монография. 2009. [Федосенко Е.В. и др.]; под науч. ред. Е. В. Федосенко. Санкт-Петербург: Речь, 121 с.

\section{Список литературы}

1. Афанасьев В.Г. 1968. Научное управление обществом. (Опыт системного исследования). М. Изд. полит. лит-ры, 384 с.

2. Бородихина С.Л. 2015. Поиск нового содержания понятия «Активная жизненная позиция» в современных общественно-политических условиях. Вестник ТГПУ, 3(156): 182-189. URL: https://cyberleninka.ru/article/n/poisk-novogo-soderzhaniya-ponyatiya-aktivnaya-zhiznennayapozitsiya-v-sovremennyh-obschestvenno-politicheskih-usloviyah (дата обращения: 12 октября 2019).

3. Задевалова С.В. 2012. Влияние развития компонентов структуры личности на формирование еe активной жизненной позиции. Вестник БГУ, 13: 89-92. URL: https://cyberleninka.ru/article/n/vliyanie-razvitiya-komponentov-struktury-lichnosti-na-formirovanieee-aktivnoy-zhiznennoy-pozitsii (дата обращения: 13 октября 2019).

4. Кабайкина О. В. 2018.Феминистическое движение в России в исторической перспективе. Общество: социология, психология, педагогика, 1: 35-39. URL: https://cyberleninka.ru/article/n/feministicheskoe-dvizhenie-v-rossii-v-istoricheskoy-perspektive (дата обращения: 10 октября 2019).

5. Маслоу А. 2014. Мотивация и личность. 3-е изд. Санкт-Петербург. Питер, 600 с.

6. Пато Т. 2006. Состояние профсоюзного движения в Европе. Научно-просветительский журнал «Скепсис». URL:https://scepsis.net (дата обращения: 16 мая 2019).

7. Поспелов Д.А. 1986. Ситуационное управление: теория и практика. М.: Наука. Гл. ред. физ.-мат. Лит, 288 с.

8. Сафарян А.В. 2008. СМИ как «четвертая власть» и институт социализации. Власть, 5: 62-65. URL: https://cyberleninka.ru/article/n/smi-kak-chetvertaya-vlast-i-institut-sotsializatsii (дата обращения: 10 октября 2019).

9. Шмарион Ю.В., Белокопытова Е.Н. 2018. Социальный портрет деловой женщины. Научный результат. Социология и управление, 4/4: 38-51.

10. Green K. 2018. Tips for Digital Engagement from Union Organizers, Labor Union News, Insight \& Tools, UnionTrack Blog, published september 11 (дата обращения: 10 октября 2019).

11. Green K. 2018. Understanding and Responding to the Major Challenges to Unions Today, Labor Union News, Insight \& Tools, UnionTrack Blog, published august 28 (дата обращения: 10 октября 2019).

12. OECD и J. Visser, база данных ICTWSS (институциональные характеристики профсоюзов, установление заработной платы, государственное вмешательство и социальные пакты), 2017. URL: http://www.uva-aias.net/en/ictwss/. (дата обращения: 12 октября 2019).

13. Union membership in the U.S. hit record low in 2018. 2018. URL: https://www.cbsnews.com/news/union-membership-declined-in-2018. (дата обращения: 12 октября 2019).

\section{References}

1. Afanas'ev V.G. 1968. Nauchnoe upravlenie obshchestvom. (Opyt sistemnogo issledovaniya) [Scientific management of society. (Experience of system research)]. M., Publ. Izd. polit. lit-ry, 384 p.

2. Borodihina S.L. 2015. Poisk novogo soderzhaniya ponyatiya «Aktivnaya zhiznennaya poziciya» $\mathrm{v}$ sovremennyh obshchestvenno-politicheskih usloviyah [Search for a new content of the concept of "Active life position" in modern socio-political conditions]. Vestnik TGPU, 3(156): 182-189. URL: https://cyberleninka.ru/article/n/poisk-novogo-soderzhaniya-ponyatiya-aktivnaya-zhiznennaya-pozitsiya-vsovremennyh-obschestvenno-politicheskih-usloviyah (data obrashcheniya: 12 oktyabrya 2019).

3. Zadevalova S.V. 2012. Vliyanie razvitiya komponentov struktury lichnosti na formirovanie ee aktivnoj zhiznennoj pozicii [Influence of the development of components of the personality structure on the formation of its active life position]. Vestnik BGU, 13: 89-92. URL: 
https://cyberleninka.ru/article/n/vliyanie-razvitiya-komponentov-struktury-lichnosti-na-formirovanieee-aktivnoy-zhiznennoy-pozitsii (data obrashcheniya: 13 oktyabrya 2019)

4. Kabajkina O. V. 2018.Feministicheskoe dvizhenie v Rossii v istoricheskoj perspective [The feminist movement in Russia in historical perspective]. Obshchestvo: sociologiya, psihologiya, pedagogika, 1: 35-39. URL: https://cyberleninka.ru/article/n/feministicheskoe-dvizhenie-v-rossii-vistoricheskoy-perspektive (data obrashcheniya: 10 oktyabrya 2019).

5. Maslou A. 2014. Motivaciya i lichnost' [Motivation and personality]. 3-e izd. SanktPeterburg. Publ. Piter, 600 p.

6. Pato T. 2006. Sostoyanie profsoyuznogo dvizheniya v Evrope [The state of the trade Union movement in Europe]. Nauchno-prosvetitel'skij zhurnal «Skepsis». URL:https://scepsis.net (data obrashcheniya: 16 maya 2019).

7. Pospelov D.A. 1986. Situacionnoe upravlenie: teoriya i praktika [Situational management: theory and practice]. M., Publ. Nauka. Gl. red. fiz.-mat. Lit, 288 p.

8. Safaryan A. V. 2008. SMI kak «chetvertaya vlast'» i institut socializacii [Mass media as the "fourth power" and the institution of socialization]. Vlast', 5: 62-65. URL: https://cyberleninka.ru/article/n/smi-kak-chetvertaya-vlast-i-institut-sotsializatsii (data obrashcheniya: 10 oktyabrya 2019$)$.

9. Shmarion Yu.V., Belokopytova E.N. 2018. Social'nyj portret delovoj zhenshchiny. Nauchnyj rezul'tat [Social portrait of a business woman]. Sociologiya i upravlenie, 4/4: 38-51.

10. Green K. 2018. Tips for Digital Engagement from Union Organizers, Labor Union News, Insight \& Tools, UnionTrack Blog, published september 11 (data obrashcheniya: 10 oktyabrya 2019).

11. Green K. 2018. Understanding and Responding to the Major Challenges to Unions Today, Labor Union News, Insight \& Tools, UnionTrack Blog, published august 28 (data obrashcheniya: 10 oktyabrya 2019).

12. OECD i J. Visser, baza dannyh ICTWSS (institucional'nye harakteristiki profsoyuzov, ustanovlenie zarabotnoj platy, gosudarstvennoe vmeshatel'stvo i social'nye pakty), 2017. URL: http://www.uva-aias.net/en/ictwss/. (data obrashcheniya: 12 oktyabrya 2019).

13. Union membership in the U.S. hit record low in 2018. 2018. URL: https://www.cbsnews.com/news/union-membership-declined-in-2018. (data obrashcheniya: 12 oktyabrya 2019).

\section{ИНФОРМАЦИЯ ОБ АВТОРАХ}

Шмарион Юрий Васильевич, доктор социологических наук, профессор, директор Ассоциации социологов «Институт социальных технологий», г. Липецк, Россия

Насонова Марина Александровна, Советник по информационной политике Федерации профсоюзов Липецкой области, г. Липецк, Россия

\section{INFORMATION ABOUT THE AUTHORS}

Yuri V. Smarion, Doctor of sociology, Professor, Director Association of sociologists " Institute of social technologies", Lipetsk, Russia

Marina A. Nasonova, Adviser on information policy of the Federation of trade unions of the Lipetsk region, Lipetsk, Russia 